half the face became insensible leading sometimes to keratitis and blindness and, if the motor root was damaged, to a skewed jaw. To Cushing's chagrin, a year after he had proudly published his technique, the neurologist William Spiller and surgeon Charles Frazier in Philadelphia described how they divided the nerve behind the ganglion, a much simpler operation that enabled selective division of the nerve without a ganglionectomy. In a brief report a few years later, despite his vested interest in the ganglion operation, Cushing quietly revealed that he had adopted their approach after his first 28 cases - a blow no doubt to his surgical pride, but a boon for his patients.

Canadians are especially indebted to Cushing for two of his students, Wilder Penfield and Kenneth McKenzie, who established the two major schools of neurosurgery in Canada, at Montréal and Toronto. Penfield and his associates at the Montreal Neurological Institute in turn trained scores of young neurosurgeons from the United States who returned to become leaders in American neurosurgery. In I922, Cushing spoke at the opening of McGill's Biological Building, emphasizing the importance of bedside teaching (introduced by Osler at Johns Hopkins) as compared to laboratory exercises. In 1929 he attended the opening of the Bibliotheca Osleriana designed to house Osler's gift of 8000 rare books. At Cushing's final visit to Montréal in 1934, on the invitation of Wilder Penfield, he presented one of his finest addresses at the opening of the Montreal Neurological Institute. He graciously paid homage to Osler for his influence in directing the Rockefeller fortune toward medical research, recognized the valuable spirit of exchange between the medical profession of the United States and Canada and gave his blessing to his student Wilder Penfield and the staff for the future of the Institute. Following Osler's example in Montréal, Cushing decided to leave his books to Yale University, where, with those of Arnold Klebs and John Fulton, the famous Medical Historical Library at Yale was founded.

There is much else of interest in this fine sweeping biography - Cushing's relations with his wife Kate
Crowell Cushing and her wrenchingly poignant letters protesting his singleminded focus on surgery at the neglect of the family; Cushing's many overseas tours during war and peace; the tragedies and high romance involving his children that included three daughters who married and remarried into the rich and famous, and in the latter part of Cushing's life, worldwide recognition for his enormous accomplishments to neurosurgery and to medicine at large.

At the time of Cushing's sixtieth birthday in 1929 he wrote Wilder Pen- field in Montréal in regard to the problem of training a neurosurgeon.

We may be setting the standard too high, too comprehensive, but it is worth striving for. ... The length of time it would take for a proper grounding in neuropathology, psychiatry, neurophysiology, etc., plus surgery, except for the occasional genius, is prohibitive. The art is long and the life short.

William Feindel

Director Emeritus

Montreal Neurological Institute

Montréal, Que.

Honorary Osler Librarian

\title{
Poem
}

\section{Until my "time of death"}

\author{
Without breath \\ the stillness of my body consumes me \\ erratic \\ uncertain \\ my heart is coerced to contract \\ a muscle no longer willing \\ a ventricle hardly filling \\ cells unable to fire \\ a body (un)-qualified to fight \\ agency pulled ever so gently \\ but ever so faithfully \\ until a tug of war exists \\ with no one on the other end to respond \\ but the wool has not been pulled over my eyes \\ lingering \\ waiting \\ wanting \\ the softness of death \\ inadvertently l'll be gone \\ vitality draining \\ quicker than the elixirs pumped into me \\ wide open \\ my body won't respond \\ futile \\ their curing-like properties \\ wasted \\ with good intentions \\ stealing \\ my anticipated hereafter \\ but another one ensues \\ that's \\ my saving grace \\ diagnosis uncertain \\ death undoubtful
}


certain as the collapse of my alveoli when they turn off the machine

certain as the rain on a stormy night in April waiting for the soundlessness unmoving

sense of vanquish that suffocates the room

and those three words can hardly depart the doctor's lips don't they know

the saving they long for does not exist

that which stirs below the surface is invisible to my eye

beyond my peripheral vision

beyond my understanding

the sanctity of a closed eye

once thought impassable

except to those that pry open my eye and apply light to an unconstricting pupil vacant

horizontal

I am at their will

the forced air pushing into my lungs

lulling me to sleep

like the perfect lullaby for the final song

pacified

persuading me

to vacate the body that has housed me for so long

"time of death"

fought to the last moment

but not by me

hoping sleep finds me soon

\section{The (un)-definitive time of death}

Many of us can intuitively feel death drawing near in a patient. Whether it is something the patient says before they fall to sleep, the colour of the skin, the shutting down of the kidneys, the cold that sheds from someone's body, or something as obvious as breath leaving the body and not spontaneously returning. And sometimes it is something so subtle, something so indescribable, but we know death is not far away.

Time of death - such a fateful expression. Such a difficult thing for most health care professionals to admit, especially when it is a patient you have come to know and respect, or when a family sits in the waiting room, waiting for you to tell them the fate of their loved one. Think of the bodies and peo- ple that you have "worked" on. Some fighting so hard to stay in this life, some fighting so hard to leave. As health care professionals it is a fine line between trying too hard and not trying enough. We can prevent death and delay death. How do we know when enough is enough? A question that still has no definitive answer.

Death is a common entity in the career of a doctor or a nurse. Most of us can all probably remember the first deaths we experienced in our professional lives. The one I remember vividly was a patient named Marie. I cared for her and her family, in her final days approaching death. I left her home at 11:oopm and she died an hour later. I remember getting a call in the morning, telling me I didn't have to go into work that evening. I remember crying as I drank my morning coffee. I wasn't "supposed" to cry. I also recall another pa- tient who died when I was present in his home with his wife by his side. Death was expected in this case. It was just the three of us there. It was 3:00am when he died, and I was at a loss for words. What could I say to this woman who had just lost her husband? What was normal? What was expected of me? She wanted to help me clean him and make him presentable before the coroner and the rest of the family got there in the morning. We bathed him in silence, together. The third death that stays with me was a patient of mine who died in the intensive care. He was old, emaciated, and you could see that life had drained out of him. It was a night shift and his wife was present, a sweet elderly lady, with no other family or friends. She was all alone and I didn't encourage her to leave that night, because I knew. She sat by his bedside and told me stories of their life together, and she told me of her worries for the future. I listened, but I was again at a loss for words.

Death is a difficult topic to discuss and many of us attempt to avoid it all together. Perhaps we hope that if we avoid it, then it doesn't exist. Yet as rational beings, we all know this is absurd. Gila Strauch completed a thesis concerning talking about death and three words from her thesis have engraved themselves on my thoughts. ${ }^{1}$ Those three words are "sense of adequacy". She tells us that experience talking about death may still not make us comfortable in talking about death, but it may empower us in the future to talk about death with a sense of adequacy. ${ }^{1}$ Talking with a sense of adequacy, striving for a sense of adequacy, when comfort is out of reach.

\section{Jennifer Lapum}

Faculty of Nursing

University of Toronto

Toronto, Ont.

\section{REFERENCE}

I. Strauch G. Lifting a veil of silence: teachers and doctors talk about death - a narrative approach to death education. [unpublished doctoral dissertation]. Toronto: University of Toronto; 1994. 